Assis, C.C. Controle da visitação pública nas piscinas naturais da Costa dos Corais em Maragogi (AL). Anais do VIII Congresso Nacional de Ecoturismo e do IV Encontro Interdisciplinar de Ecoturismo em Unidades de Conservação. Revista Brasileira de Ecoturismo, São Paulo, v.4, n.4, 2011, p. 584.

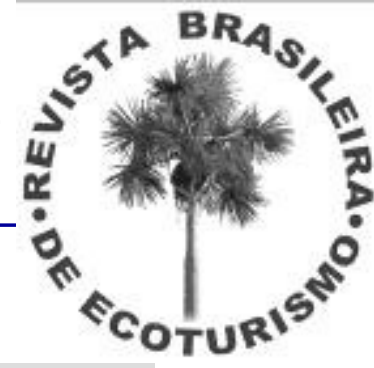

\title{
CONTROLE DA VISITAÇÃO PÚBLICA NAS PISCINAS NATURAIS DA COSTA DOS CORAIS EM MARAGOGI (AL)
}

\author{
Cláudia Cordeiro de Assis* \\ *Universidade Anhembi Morumbi/ Instituto Federal de Alagoas \\ E-mail: claudiacordeirinho@hotmail.com
}

O presente estudo promove o entendimento da importância do controle da visitação pública nas piscinas naturais do Município de Maragogi em Alagoas. Para o desenvolvimento da pesquisa utilizou-se de bibliografias referente às Áreas de Preservação Ambiental (APA) e Legislação Ambiental, observação in loco e acompanhamento de pesquisadores. Maragogi faz parte da Costa dos Corais, uma Área de Preservação Ambiental (APA) criada em 1997, que compreende 13 municípios ao longo de seus $135 \mathrm{~km}$, entre o litoral norte de Alagoas e o sul de Pernambuco. Os recifes presentes na costa fazem parte de uma formação de barreira de corais e é definida como a segunda maior e mais importante do mundo. Com a maré baixa, formam-se piscinas naturais que unidas à presença de corais, contempla numerosas espécies endêmicas de inestimável beleza, contribuindo por representar o principal atrativo da região. As piscinas naturais das Galés de Maragogi são atualmente, o segundo destino turístico no estado de Alagoas, só perdendo em número de visitantes para a capital, Maceió. Os principais impactos causados pela atividade turística desordenada até 2009, nesta região eram a ancoragem das embarcações; pisoteio sobre os recifes; a retirada de organismos ornamentais; aumento da turbidez da água e a pesca irregular, além da falta de preparo e descuido com a segurança e salvaguarda da vida humana. Com a exploração intensiva da iniciativa privada, nessa área de patrimônio público, através dos passeios, mergulho autônomo, vendas de fotos subaquáticas, comércio de alimentos e bebidas, agravaram-se ainda mais a degradação. A partir de janeiro de 2010, as ações referentes à instrução normativa $n^{\circ}$. 08 de 29 de dezembro de 2009 passaram a regular o ordenamento da atividade de turismo e demais formas de exploração econômica das piscinas naturais de Maragogi, delimitando o número máximo de visitantes nas piscinas para 720 pessoas/dia; somente as embarcações autorizadas passam a realizar o passeio às piscinas naturais respeitando 0 limite demarcado pelo zoneamento estabelecido pela APA da Costa dos Corais; a proibição da permanência das embarcações na zona de uso público no período de maré cheia, o impedimento da comercialização de bebidas e comidas na zona de uso público, sendo fornecidos somente no interior das embarcações autorizadas. Efetuadas as análises e observações, foi possível identificar que a cultura da cooperação, entre os empresários locais, a comunidade e Governo através do Arranjo Produtivo Local de Turismo - Costa dos Corais instigaram a busca de ações emergenciais de uma gestão sustentável, contribuindo para a redução dos impactos nas piscinas naturais do destino turístico, através da regulamentação da atividade, com punição prevista em lei. Entretanto, até a presente data, não existe um plano de manejo ou mesmo um zoneamento de toda a área desta APA.

Palavras - chave: Controle; Costa dos Corais; Maragogi (AL). 